\title{
SWAYAM: The Platform for Modern and Enhanced Online and Flexible Education- $A$ Knowledge Survey
}

\author{
P.K. Paul ${ }^{*}$, A. Bhuimali ${ }^{2}$, K.S. Tiwary ${ }^{3}$, P.S. Aithal ${ }^{4}$ and R. Rajesh ${ }^{5}$ \\ ${ }^{I}$ Executive Director, MCIS, Raiganj University (RGU), West Bengal, India \\ ${ }^{2}$ Vice Chancellor, Raiganj University, West Bengal, India \\ ${ }^{2}$ Professor of Mathematics \& Head, CIS, Raiganj University, West Bengal, India \\ ${ }^{4}$ Vice Chancellor, Srinivas University, Karnataka, India \\ ${ }^{5}$ Principal, Rohini College of Engineering and Technology, TN, India \\ *Corresponding author: pkpaul.infotech@gmail.com
}

\begin{abstract}
Information Technology has changed the entire arena of modernization. In every sectors and areas Information Technology and Computing is useful and applicable and this trend is growing. SWAYAM is the platform which is responsible for the online and advanced self learning initiated and started by the Government of India. This is helpful for those who are studying and also working. The best way and biggest efforts for the self-study by the public sector initiative is SWAYAM. Under this scheme various organizations and institutions dealing with the academics can interact and do the needful in their online and similar kind of education. Here in this initiative, initially faculty members from the reputed organizations became participated and delivered the courses and lectures and among these important are IIT Bombay, IIT Madras, IIT Kanpur, IIT Guwahati, University of Delhi, Jawahar Lal Nehru University, IGNOU, IIM Bangalore etc. And gradually other organizations have been added into the catalogues. All the courses under SWAYAM is offered fully free and important to note that in some cases charges are required viz. Offering Award or Certification on the chosen area etc. The craze of SWAYAM is increasing and gaining popularity in India other countries. This paper is on basics of SWAYAM and including its characteristics and basics. The paper highlighted traditional and modern concept of e-learning as well. The paper is about concept and features of SWAYAM as well.
\end{abstract}

Keywords: SWAYAM, Online Education. E-Learning, Mobile Education, HRD, GoI, Self Study, Higher Education, Digitalization, Digital India

SWAYAM is an instrument for self-learning and online education and it is providing opportunities for a life-long learning. Hundreds of courses are offered in this platform and here virtually every course is 
for the university / college / school level and importantly most of the courses are offered by the teachers in India and elsewhere ${ }^{[1],[5]}$. Any studying in any universities or college can transfer the credits and may enhance the portfolio or academic record. Here in this initiative courses are delivered by the reputed organizations and universities viz. IIT Bombay, IIT Madras, IIT Kanpur, IIT Guwahati etc. SWAYAM program is initiated by the Government of India and designed to achieve the three cardinal principles of Education Policy viz.-

$\square$ Access,

$\square$ Equity and

$\square$ Quality.

And the development in this spectrum is increasing and growing rapidly. It is worthy to note that different state government also doing well in this regard of improving infrastructure of online education ${ }^{[2],[7]}$.

\section{Objective}

The paper is conceptual in nature and theoretical and mainly deals with following aim and agenda:

$\square$ To know about the basics of online systems and e-learning systems including its basics features.

$\square$ To learn about the initiation of the SWAYAM and its initial growth in Indian context.

$\square$ To know about the basic role and importance of the SWAYAM and its increasing scope for the betterment of online and e-education.

$\square$ To learn about the basic categories of SWAYAM and its importance in Indian Higher Education specially HEIs.

$\square$ To learn about the challenges and issues of SWAYAM and future potentialities for building a healthy and solid knowledge based society.

\section{Methods}

The current paper is conceptual in nature and deals with the basics of SWAYAM; the online and self study platform started by the Government of India under the supervision of Ministry of HRD. The core aim of the paper is to know the basics of SWAYAM including its features and characteristics, role and importance. Hence simply the official websites have been consulted for this study and moreover, some of the reputed and biggest higher educational institutions sites are analyzed to know about the latest of the area and future potentialities in brief.

\section{SWAYAM: An Overview}

SWAYAM is stands for Study Webs of Active -Learning for Young Aspiring Minds programme that has initiated by the Ministry of Human Resource Development (MHRD), Government of India and here different professors from different subjects are engaged and moreover the faculties from the reputed bodies viz. IITs, IIMs, central universities will offer online courses to the citizens of India ${ }^{[3],[6],[9]}$. 
SWAYAM is an instrument for self-actualisation responsible for the life-long learning. Here learner can choose from hundreds of courses, virtually every course that is taught at the university / college / school level and these shall be offered by best of the teachers in India and elsewhere. Student studying in any college and university can earned the credit by taking courses and moreover persons working or not working may engaged with the SWAYAM and even persons working in school or out of school may interact with SWAYAM it is offered extended and huge educational opportunity to gain knowledge.

All the courses under SWAYAM programme is free though fees would be applicable in case of less students or students seeking certifications. Here is the few facts on SWAYAM:

$\square$ In the first phase the SWAYAM program has been started in different organizations and educational institutes viz. IIT Bombay, IIT Madras, IIT Kanpur, IIT Guwahati, University of Delhi, Jawahar Lal Nehru University, IGNOU, IIM Bangalore, IIM Calcutta, Banaras Hindu University and lateron faculties from foreign universities also been added into the program.

$\square$ There are many areas where SWAYAM platform may be added viz. engineering education, social science, energy, management, basic sciences. Initially one crore students are expected to benefited in 2 to 3 years timeframe.

$\square$ India is one of the few countries in the world has this kind of online interactive learning systems and platform. Ultimately this provides wide-range of audio and video lectures, reading material and complete assessment system.

$\square$ The then President of India (Dr. Pranab Mukherjee) initiated the SWAYAM portal to offer quality and advanced education to the doorstep to everyone. Moreover apart from this, another platform called SWAYAM Prabha also been enhanced and gear-up the 32 DTH channels; it is dedicated for the advanced telecasting and advanced content free of charge with the help of GSAT-15. The logo of SWAYAM is depicted in Fig. 1.

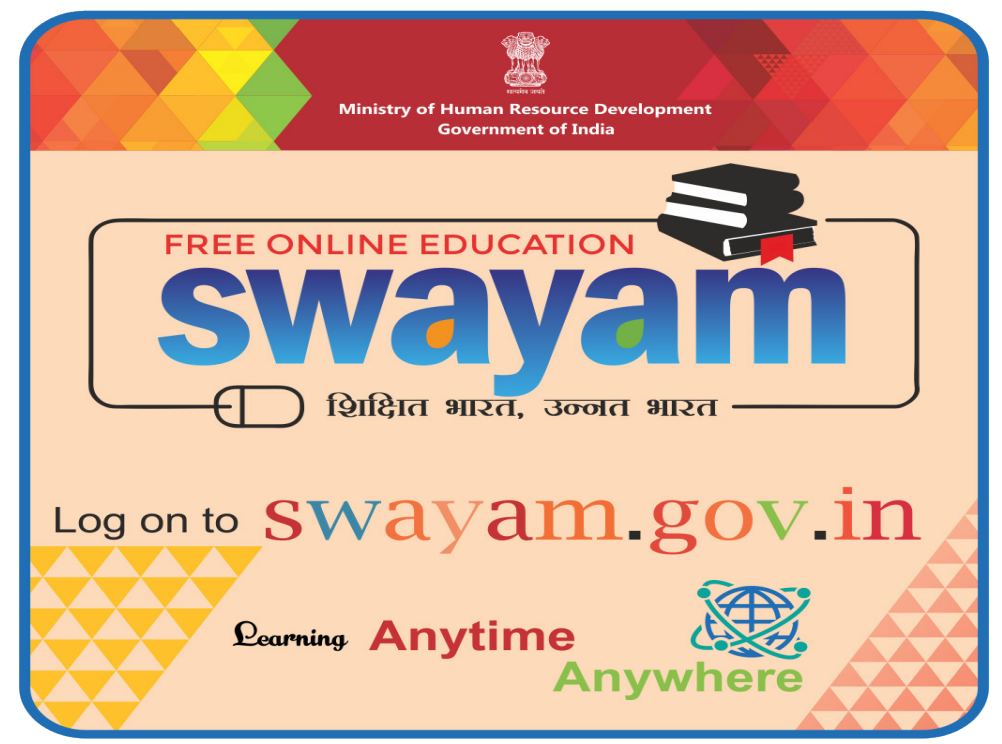

Fig. 1: Logo of the Swayam 


\section{SWAYAM: Applications and Core Agenda}

SWAYAM started by the MHRD, Government of India and responsible for the three cardinal principles of Education Policy (access, equity and quality) and importantly the objective of this effort is offering quality and advanced teaching learning resources to the advanced learners and also most disadvantaged pupils. SWAYAM is also offered to bridge the gap of digital divide those who are untouched by the digital revolution and also helpful for the improving the knowledge and ultimately it helps in developing and creating knowledge economy ${ }^{[6],[8],[10]}$. The system is lies on advanced and smart IT platform for hosting all the courses and importantly it is taught for the students of standard of Nine (9) to till post-graduation and accessible to anyone and anywhere at any time. Most of the courses under SWAYAM is interactive and designed by the best teachers in the India and also available and free of cost to Indians. 1,000+ faculty and teachers from different branches throughout Country actually participated in preparing SWAYAM courses and program ${ }^{[12],[14]}$. SWAYAM courses are having 4 quadrants viz.

video lecture/s

$\square$ Reading material that can be downloaded/printed

$\square$ self-assessment tests and quizzes

$\square$ online discussion forum for clearing the doubts and knowledge.

For enhancing and enriching learning experience different types and good amount of audio-video and multi-media / technology are using in this systems ${ }^{[1],[13]}$. The best quality contents are produced for the SWAYAM. And for its improvement total nine National Coordinators have been appointed and they are includes (including their roles):

$\square$ AICTE (self-paced and international courses)

$\square$ NPTEL (for engineering)

$\square$ UGC ( non technical post-graduation education)

$\square$ CEC (under-graduate education)

$\square$ NCERT \& NIOS (school education)

$\square$ IGNOU (school students)

$\square$ IIMB (management studies)

$\square$ NITTTR (Teacher Training program).

Candidates opting the course shall have the certificate on successful completion with a little fee. Sometimes there will be an assessment by proctored examination and the marks/grades secured in this exam may be helpful for the academic record of the students and credit transfer. It is important and worthy to note that UGC has already issued the UGC (Credit Framework for online learning courses through SWAYAM) Regulation 2016. The core aim of this is include but not limited to the advising the HEIs and Universities to identify courses and moreover these can be transferred in to the academic record of the candidates completed under the SWAYAM.

It has learned that SWAYAM platform has been developed by the Ministry of Human Resource Development and All India Council for Technical Education and here Microsoft play a vital role. 
Ultimately the system is capable in hosting 2000 courses and moreover 80000 hours of learning for different categories viz. school, under-graduate, post-graduate and specialized areas viz. engineering, law.

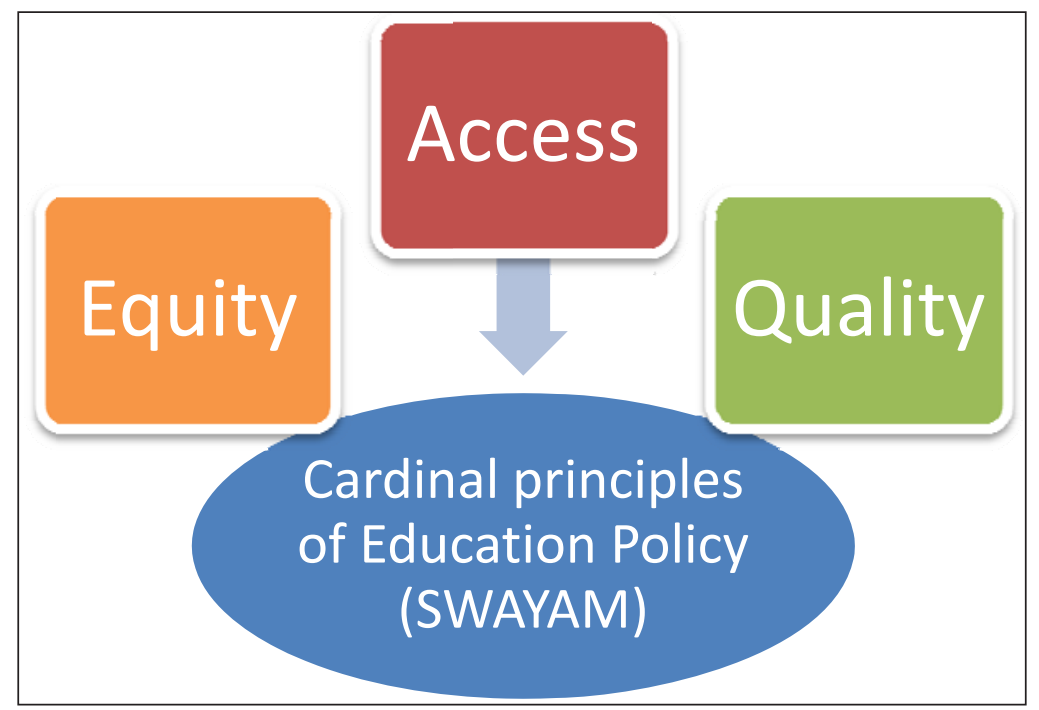

Fig. 2: The core of SWAYAM profile

\section{SWAYAM: Categories}

The division of SWAYAM consist with the following division and branches and concentration areas viz.:
$\square$ Education
$\square$ Engineering
$\square$ NRC
$\square$ Architecture \& Planning
$\square$ General
$\square$ Humanities
$\square$ Library and Information Science
$\square$ Management
$\square$ Mathematics
$\square$ Open Design School[15],[16].

\section{Findings}

The current topic and research area has been identified following major concern (such as):

$\square$ SWAYAM is an instrument for self learning and online education and it is providing opportunities for a life-long learning. 
$\square$ The program is initiated by the MHRD but several bodies (namely ten) are performing their best to improve the systems.

$\square$ SWAYAM is offered to the candidates having studentship or without studentship and also from the employment track.

$\square$ The program SWAYAM is also comes with the credit system which helps in educational degrees etc for achieving the award/ credit transfer.

$\square$ SWAYAM program is comes with certification as well with nominal charges, if required. And this trend is growing.

\section{Suggestion}

The SWAYAM program gaining popularity in rapid scale and different stakeholders are using SWAYAM for its advantage, herewith few suggested contents viz.

$\square$ The SWAYAM platform needs improvement in modernization in delivery in other mobile apps etc for smarter delivery.

$\square$ It is important to note that the SWAYAM already started initiation in Certification program and later on the other programs leading to Bachelors or Masters degree may also be started and in this regard collaboration with other universities may be carried out for better and smarter knowledge delivery.

$\square$ Online professional degrees may also started in this scheme. Moreover the subject range may be more than the present.

$\square$ It is worthy to note that program may be offered by the faculty members of the private universities and Higher Educational Institutions.

\section{CONCLUSION}

The society is developing rapidly and here different kind of organizations and institutions are playing rapid and advanced role. The technologies, viz. Information Technology and Digital Technology playing a leading role the content related affairs viz. collection, management and designing etc. It is important to note that SWAYAM is in initial stage and thus in future no doubts will be helpful in other sphere of knowledge; including cultivation of knowledge ${ }^{[7],[17],[18]}$. It is obviously important to note that SWAYAM program may be enhanced based on requirement and suggestion from the existing and current problems. Different departments, council and bodies may gear-up for better and healthy knowledge management and educational delivery for those having advanced knowledge or skills or parallel knowledge for current students.

\section{REFERENCES}

1. Altbach, P.G. and Knight, J. 2007. The internationalization of higher education: Motivations and realities. Journal of studies in international education, 11(3-4): 290-305.

2. Alcorn, B., Christensen, G. and Kapur, D. 2015. Higher education and MOOCs in India and the Global South. Change: The Magazine of Higher Learning, 47(3): 42-49. 
3. Barreiro-Gen, M. and Novo-Corti, I. 2015. Collaborative learning in environments with restricted access to the internet: Policies to bridge the digital divide and exclusion in prisons through the development of the skills of inmates. Computers in Human Behavior, 51: 1172-1176.

4. Dutta, U. and Das, S. 2016. The digital divide at the margins: co-designing information solutions to address the needs of indigenous populations of rural India. Communication Design Quarterly Review, 4(1): 36-48.

5. Gereffi, G., Wadhwa, V., Rissing, B. and Ong, R. 2008. Getting the numbers right: International engineering education in the United States, China, and India. Journal of Engineering Education, 97(1): 13-25.

6. Göransson, B. and Diep, D.D.N. 2016. Bridging the Digital Divide-The Role of the Scientific and Technological Information Stations in Rural Areas of Dong Nai Province. VNU Journal of Science: Policy and Management Studies, 32(2).

7. Gupta, A. 2008. International trends and private higher education in India. International Journal of Educational Management, 22(6): 565-594.

8. Kaveri, A., Gupta, D., Gunasekar, S. and Pratap, M. 2016. Convergence or Divergence: MOOCs and Legacy of Higher Education Outcomes. In MOOCs, Innovation and Technology in Education (MITE), 2016 IEEE $4^{\text {th }}$ International Conference on (pp. 20-24). IEEE.

9. Mohapatra, S. and Mohanty, R. 2017. Adopting MOOCs for afforable quality education. Education and information technologies, 22(5): 2027-2053.

10. Nisha, F. and Senthil, V. 2015. MOOCs: Changing trend towards open distance learning with special reference to India. DESIDOC Journal of Library \& Information Technology, 35(2): 82-89.

11. Paul, P.K. and Lata Dangwal, K. 2014. Cloud Based Educational Systems and Its Challenges and Opportunities and Issues. Turkish Online Journal of Distance Education, 15(1): 89-98.

12. Paul, P.K., Dangwal, K.L. and Garg, A.K. 2012. Education technology and sophisticated knowledge delivery. TechnoLearn: An International Journal of Educational Technology, 2(2): 169-176.

13. Paul, P.K., Dangwal, K.L. and Chettri, R. 2013. Quadruple Play Network: Emphasizing its Possibilities for Smarter University Education Especially Online Knowledge Delivery Model. Learning CommunityAn International Journal of Educational and Social Development, 4(1): 89-96.

14. Pujar, S.M. and Tadasad, P.G. 2016. MOOCs-an opportunity for international collaboration in LIS education: A developing country's perspective. New Library World, 117(5/6): 360-373.

15. Singal, N. 2006. Inclusive education in India: International concept, national interpretation. International journal of disability, development and education, 53(3): 351-369.

16. Soma, K., Termeer, C.J. and Opdam, P. 2016. Informational governance-A systematic literature review of governance for sustainability in the Information Age. Environmental Science \& Policy, 56: 89-99.

17. Tayade, M.C. and Kulkarni, N.B. 2011. The Interface of technology and medical education in india: current trends and scope. Indian Journal of Basic \& Applied Medical Research, 1(1): 8-12.

18. Venkatesh, V., Sykes, T.A. and Venkatraman, S. 2014. Understanding e-Government portal use in rural India: role of demographic and personality characteristics. Information Systems Journal, 24(3): 249-269. 
